\title{
11 \\ Kinship in Mind: \\ Three Approaches
}

Doug Jones

Social anthropologists mostly study kinship as a principle of social organisation. But there is also a psychological and cognitive side to human kinship, involving questions like: How do people recognise others as kin of one sort or another? What do kin categories mean and how are they related to one another? What, if anything, distinguishes thinking about kinship from other varieties of social cognition?

Different schools of anthropology offer very different answers to these questions. Here I review three approaches to the psychology of kinship. One has its roots in evolutionary theory and human/nonhuman comparisons. The second is concerned with symbolism, culture, and the natives' explicit theories of procreation and kinship. These approaches are likely to be familiar to students of evolution and human behaviour, and cultural anthropology, respectively. The third approach stems from recent developments in cognitive science, especially in the study of specialised domains of cognition. This approach is newest, and probably least familiar to most anthropologists and even to most cognitive scientists, so it receives most attention here. I argue that human beings have a specialised cognitive system-which can be called 'kinship core cognition' or 'kinship conceptual structure'-comprising a set of universal building blocks for organising knowledge of kin and kin categories in an abstract kinship space. Much of the success of formal methods in the study of kin 
categorisation, as carried out by authors like Floyd Lounsbury (1964), Ward Goodenough (1965), Harold Scheffler (1978), Dwight Read (2010), Murray Leaf (Leaf and Read 2012) and others, depends on these building blocks. They also turn out to play a role in generating social organisation-at least so I argue in a discussion of Aboriginal Australian kinship systems. In particular, Hal Scheffler's monumental work on Australian kin classification is a major influence on the last section of the paper, which proposes that the conceptual structure of kinship plays a role in generating not just kin terminologies but social organisation.

\section{Kinship and attachment}

For evolutionary biologists, kinship means genetic relatedness. This can be defined numerically, as the coefficient of relatedness of organism B to organism A; the expected number of copies of a gene in B that are identical by descent with a copy of that gene in $A$, over and above whatever gene copies B shares with A by virtue of being part of the same population. (The last part means that the coefficient of relatedness is defined relative to some background population.)

Natural selection is expected to build organisms that are sensitive to coefficients of relatedness, for several reasons. First, in most populations, the gene pool contains some fraction of deleterious recessive alleles, which are harmless in one dose (as heterozygotes), but harmful in a double dose (as homozygotes). Since the offspring of genetically related parents are more likely to be genetically identical-homozygous - at any given genetic locus, they are more likely to get a double dose of deleterious recessives, and to suffer reduced fitness. So, natural selection is expected to favour an inhibition on mating with close relatives. Second, an organism that behaves altruistically to a genetic relative, acting in a way that reduces its own fitness, while increasing the fitness of its relative, will end up leaving more copies of its genes in the next generation than a less altruistic one. So natural selection is expected to favour altruism toward genetic kin, depending on their coefficient of relatedness.

Such is the theory. But organisms cannot read one another's genotypes directly. Inbreeding avoidance and altruism based on kinship require some machinery for kin recognition, sensitive to phenotypic or other cues correlated with kinship. Two broad classes of mechanisms are known to biologists - phenotype matching and associational cues. Both have been 
demonstrated in a variety of nonhuman organisms (Hauber and Sherman 2001; Hepper (ed.) 1991; Chapais and Berman (eds) 2004; Parr and de Waal 1999; ), and there is some evidence they operate in humans as well, summarised below.

\section{Phenotype matching}

Genetically similar individuals are likely to be phenotypically similar, so natural selection may favour rules of thumb that say 'Avoid mating with ... be extra nice to ... those who resemble you.' Human beings seem to be sensitive to olfactory cues in choosing mates, preferring the smell of those who differ at genetic loci in the major histocompatibility complex (MHC) (Porter and Moore 1981; the MHC controls much of the immune system in vertebrates). Friends tend to be more genetically similar than expected by chance at loci controlling olfaction (Christakis and Fowler 2014). People judge faces that have been morphed to resemble themselves as more trustworthy (DeBruine 2002), and (in the case of child faces) more appealing (DeBruine 2004). Behavioural similarity also may serve as a heuristic cue for kinship (Park and Schaller 2005).

\section{Associational cues}

Primates in general (Silk 2001; Pusey 2005), probably including humans, rely more on associational cues than on phenotypic similarity to recognise kin. An early proposal invoked associational cues as a proximate mechanism in inbreeding avoidance. Edward Westermarck (1903) argued that children raised together from a young age would later show a lack of erotic interest in one another. In most cases these individuals would be siblings, and the Westermarck effect would make inbreeding less likely. This effect is well-documented among nonhuman animals, under the label of negative sexual imprinting (Pusey 2005). In humans, test cases arise when nonsiblings are raised together but sexual relations are not discouraged, or are even encouraged. Several versions of this natural experiment have been studied, involving adolescents raised together in nursery groups in Israeli kibbutzim (Talmon 1964; Shepher 1971), married cousins raised in the same extended families in Lebanon (McCabe 1983), and Taiwanese couples where the girls were adopted at an early age into the families of their husbands-to-be (Wolf 1995). These all support Westermarck's hypothesis, which stands as the most plausible explanation for the near-universal avoidance of nuclear family incest. An amplified 
version of Westermarck's hypothesis has recently been proposed by Debra Lieberman, John Tooby and Leda Cosmides (2007; Lieberman 2009). They argue for two psychological mechanisms regulating kinship sentiments, childhood coresidence, and observing one's mother caring for a newborn. The evidence is that both sorts of cues affect both altruism and sexual indifference.

This research suggests some obvious extensions. If older siblings bond to an infant cared for by their mother, then men may bond to an infant cared for by a long-term sexual partner. And both sibling and paternal bonds may extend to an infant known to have been born to a woman even when she is not directly observed caring for the child.

\section{Kinship and cultural models}

In the documentary Stories We Tell, filmmaker Sarah Polley (2012) tells the story of her discovery that her late mother's husband is not her biological father. A crucial moment comes when she learns that a DNA test has assigned paternity to one of several potential genitors with 99+ percentage probability. She comes to know her biological paternity with much more certainty than if she relied just on an evolved modular kin-recognition system, which in this case could never support more than suspicions. But this only works because Polley accepts what she has been told about genes and genetic testing. Her theories about the biology of kinship, acquired as part of her culture, affect her beliefs about who her 'real' kin are and the strength of her attachment to them.

This clearly poses a puzzle, because formal theories and informal cultural models of kinship are not guaranteed to agree with the modern biologist's theories of genetic relatedness and genetic inheritance. Before the twentieth century even experts had some strange ideas. Charles Darwin, for example, made a considerable effort, mostly unsuccessful, to discover the nature of heredity. His investigations convinced him that traits acquired during the course of an organism's lifetime could be passed on to its offspring (1868: vol. II: 23-24). He was also convinced by reports of telegony in horses and pigs, in which offspring supposedly inherited traits from their mothers' previous mates (vol. I: 403-05, vol. II: 264). He tried to come up with a physiological mechanism that would make these unusual modes of inheritance possible. 
Similar beliefs-in the inheritance of acquired traits and telegony (in the guise of partible paternity) — are recorded for many societies (e.g. Beckerman and Valentine (eds) 2002). And anthropologists have reported other exotic native statements about procreation. In some cases, the substance of a child is said to come only from its father, with the mother being just an incubator. Conversely, according to some anthropologists, paternity and even the necessity of intercourse in conception may be denied. (For the Trobriand Islands, see Malinowski 1987: 142-66; but cf. Weiner 1988: 53-58. For Aboriginal Australia, see review in Hiatt 1996: 120-41, and a sceptical take in Scheffler 1978: 5-13.)

Taken at face value, these accounts raise the possibility that kinship means something different in different cultures. Some anthropologists go so far as to propose that the western concept of 'kinship' does not translate everywhere. Perhaps anthropology needs to replace the study of kinship with the study of an open-ended fuzzy domain of 'relatedness.' Relatedness might result not just from intercourse or parturition, but from sharing a wet nurse or sharing meals, from being born at the same time or place, or working together (Sahlins 2013).

This approach is defended at some length by Janet Carsten in an ethnography of Malay kinship. According to Carsten, the Malay villagers she studied conceptualise kinship as shared blood. While this sounds close to prescientific western ideas of blood kinship, Carsten argues that her subjects saw blood as malleable. 'Blood changes through life - as does kinship' (1997: 107). Blood is manufactured from food, especially heated food, so people sharing food at the same hearth-including adopted children - come to have the same blood, and 'children's physical appearance and character are believed to be strongly influenced by the people they reside with' (ibid.: 60). Carsten herself was told that she was coming to resemble members of her host family. Also, blood is transformed into milk, so children who share a wet nurse come to be kin, and are covered by an incest taboo, even if they have different mothers and fathers.

These Malay beliefs about relatedness and inheritance have different sources. Concepts of 'milk kinship' and related incest taboos are apparently of Muslim origin. The idea that hereditary traits are not fixed at birth, but unsettled throughout life, up to death, is widespread in the Austronesian-speaking culture area, and may originate in a body of custom, or adat, going back to a founding population of farmers 
and mariners on Formosa (Bellwood, Fox and Tryon (eds) 2006). It is interesting to note that many of the strong claims about the cultural construction of kinship have come from anthropologists working with Austronesian-speaking populations. On Yap, in Micronesia, it has been claimed that natives denied the role of intercourse in conception and considered that a woman's children become kin to her husband because she works on his land (Schneider 1984). In Polynesia, adoption and coresidence were supposed to generate relatedness (Caroll (ed.) 1970; Brady (ed.) 1976). On Madagascar, it is said that inherited potential is flexible, and that membership in hereditary groups is fixed at death rather than birth (Astuti 2001).

These accounts seem hard to square with either the evolutionist's view that human behaviour toward kin is governed by evolved mechanisms of kin recognition, or the classic social anthropologist's view that genealogy is the universal underpinning of kinship. It is important to note, therefore, that there are good reasons to question whether the culturalist account is really the whole story about kinship. First, there are serious questions about whether the ethnographic evidence really supports the strong theoretical claims made for it. For Malaysia, Warren Shapiro (2011) cites ethnographies that seem to undermine Carsten's more extreme claims. For Yap, Adam Kuper (1999) is sceptical on a number of grounds. For example, based on David Labby's (1976) work, either Schneider's understanding of Yapese conception beliefs was seriously incomplete, or those beliefs changed radically in just 20 years. For Oceania, Joan Silk (1980) argues that adoption overwhelmingly involves closely related families, and is largely consistent with predictions from the theory of kin selection.

Second, research in cognitive science shows that what people say they believe, and how they think, are two different things. Explicitly avowed theories and models are an imperfect guide to the implicit concepts that may actually guide reasoning (Kahneman 2011). Consider religious beliefs, for example (Barrett 1999). Adherents of the major monotheistic religions explicitly avow that God is omnipotent, and can do any number of things at once, but when asked to reason about God's actions they imagine that God finds it easier to act sequentially rather than simultaneously. There may be a similar disconnect in the psychology of kinship. Some evidence comes from the Vezo of Madagascar (Astuti 2001; see also Bloch, Solomon and Carey 2001, for the Zafimaniry, another Madagascan group). Like many other Austronesian speakers, the Vezo profess that individuals take on the character of their surroundings. They claim, for example, that adoptees grow to resemble their adoptive parents, and that children who 
spend a lot of time associating with missionaries turn light skinned. Yet in psychological tests involving scenarios of infants switched at birth to a different family, Vezo adults clearly differentiate between physical traits resulting from biological parentage, and social traits influenced by adoptive parents - between nature and nurture. In short, at some level, Vezo do not reason in accordance with their professed beliefs. Rita Astuti (2001) argues that these beliefs constitute an ideology, which supports cultural practices like adoption and the symbolic demotion of nuclear family ties in favour of wider connections. However, this explicit ideology coexists with an implicit concept of kinship close to the western one.

\section{Kinship and conceptual structure}

Suppose we try to split the difference between the evolutionist and the culturalist account of kinship. Perhaps the evolutionists are right in thinking that people have emotional machinery that leads to the formation of attachments, the strength of which roughly correlates with genetic distance via some proximal cues. Perhaps the culturalists are right in thinking that there is wide variation in cultural models of how people come to be related one another, with less of a common core across cultures than one might expect. The evolutionist account might work best for behaviour toward close kin, while the culturalist account might work best for behaviour toward distant relatives (Rodseth and Wrangham 2004).

I think, however, that neither the standard evolutionist account, nor the culturalist account, nor a blend of the two offer a full theory of human kinship. Kinship also includes a special-purpose cognitive/conceptual side, evident in kin terminology and other areas of social interaction, where interacting individuals draw on their common knowledge of conceptual universals to construct shared codes for categorising and dealing with kin. Kin terminologies reveal the working of the kinship part of the mind with exceptional clarity. Across cultures, there are regularities in which kin types are terminologically merged and separated, or otherwise linguistically unmarked and marked, that implicate a common conceptual structure underlying local vagaries in theories of relatedness and procreation (Jones 2010). These regularities include:

1. Kin terminologies form a closed system, a separate semantic domain. Terms for kin-like father or aunt in English-are distinct from terms for other social relationships, like boss or friend. Words for kin are sometimes used for nonkin as well, but for core kin terms it can 
be shown, sometimes by the evidence of marked linguistic forms like godfather, sometimes by patterns of usage, that these nonkin uses are secondary.

2. Kin terminologies are systematically related to one another. Kin terminologies form around a core set of terms, which can be combined to give terms for more distant relatives. For example, father's sister and mother's sister are both aunt in English. These mappings are highly structured. Thus aunt is a nondisjunctive category, built from the natural classes of parent and sister. Disjunctive categories—a single word for mother and father's sister, which excludes mother's sisterare logically possible, but rare or non-existent (Hage 1997).

3. Kin categories map onto genealogical categories. Words like father, mother and aunt can be assigned to positions on genealogical charts, and this is true of kin terms across cultures. That kin categories are genealogically structured is not a logically necessary truth, but one of the great empirical discoveries of anthropology.

4. Kin terms are subject to formal analysis, using methods analogous-or even identical - to those in linguistics. A large literature demonstrates the success of formal analysis of kin terms, although there are differences among scholars over preferred techniques. The parallels with formal linguistics have been noted by many authors (Greenberg 1966, 1990; Jones 2010; Kroeber 1909; Lévi-Strauss 1969).

I suggest that the best explanation for these findings is that kinship is governed not just by machinery for emotional attachment, but by a specialised panhuman conceptual system. In the rest of this section, I consider how this hypothesis fits within a larger universe of overlapping research programs in cognitive science, which go under the names of conceptual structure (Jackendoff 2002; Pinker 2007), domain specificity (Barkow, Cosmides and Tooby 1992; Hirschfeld and Gelman (eds) 1994) and core cognition (Carey 2009).

What these research programs have in common is the theory that the human mind comes equipped, from birth, not just with sensory, motor and motivational systems, but with a system of innate abstract ideas. In a sense, this amounts to trying to put Immanuel Kant's philosophy of knowledge on a scientific footing (Kant 2009; Kitcher 1990; Pinker 2007: 153-233). Kant argued that concepts of number, space, time, and causation could not be derived from experience, but had to be already present in the mind to organise the raw material of perception (2009). For example, in the 
absence of some preexisting conceptual structure relating to causation, nothing in experience implies a distinction between 'A happens, then $\mathrm{B}$ happens' and 'A causes B'. In the modern cognitive science reworking of this argument, innate conceptual structure is organised into a number of domains. These domains probably include interconnected concepts: of stuff and things in space; of processes and events in time; of quantity, including amount, number, and likelihood; of force and causation; of life, animacy and living kinds; of the minds of others; and of possession and other social relationships and responsibilities. On the account proposed here, the conceptual structure of kinship is a major subdivision of the last of these domains.

Below I review two domains of conceptual structure: the domains of objects in space and of kinship. The first is of interest here because the conceptual structure of objects in space seems to be a kind of master domain, from which derivative domains, including kinship, borrow much of their organisation. This means that when we review the conceptual structure of kinship, it will turn out to be organised around an abstract 'kinship space'.

A major source of evidence for conceptual structure comes from language, with different conceptual domains attaching themselves to different linguistic domains. In English, for example, the conceptual structure of space attaches particularly to spatial prepositions like on, in, over, along, and so on. Other languages use other word form classes (Levinson 2003; Levinson and Wilkins (eds) 2006). Languages vary not only in the form classes they recruit to express spatial conceptual structure, but in the range of spatial positions covered by a given construction. For example, English ' $\mathrm{A}$ is on B' requires that A and B be in contact ('The table lamp is on the table', but 'The hanging lamp is over [or above, but not on] the table'). However, English on does not require that A be above B ('The picture is on the wall'). By contrast, Japanese ue works differently, applying to the first two cases but not the third (Levinson and Wilkins 2006a: 554).

Underlying this variation are some common principles that suggest the language of space is built on a common foundation across cultures. A review of cross-cultural evidence suggests that the prototypical spatial scene involves 'a relatively small, manipulable, inanimate, movable and independent figure object ... in close contiguity with a relatively large, relatively stationary ... ground object-for example a cup on a table' (Levinson and Wilkins 2006b: 515). Normally the smaller object is 
the figure, or focus of attention, but exceptionally the figure/ground relationship is reversed. Spatial terms recognise variations from this and a few other prototypical scenes corresponding to a limited number of distinctive features - whether or not the figure is in contact with the ground, or above it, or enclosed by it, and so on. Across languages, the number of distinctive features organising the language of space is probably in the low tens, with some features very widely used, others less so.

The kind of information conveyed by the language of space is limited, implying that the representation of space in conceptual structure is pretty schematic compared to its representation in perception (Pinker 2007: 174-88). Scale is largely absent: 'The plane is on the tarmac' gets the same preposition as 'The fly is on the table'. Metric information (' 10 metres', '30 degrees') is largely omitted from prepositions and other spatial terms, as is most information about shape, except for a few dimensional contrasts (0-D/point-like versus $1-\mathrm{D} /$ elongated versus $2-\mathrm{D} / \mathrm{flat})$, and much other important information, like the worth of the object on the table. Almost any such information can of course be conveyed by stringing words together into sentences ("The lamp is on the table, 18 inches from the edge.' Or 'Reno is 427 miles west by southwest of Salt Lake City.'), but this falls outside the scope of the language and conceptual structure of space, properly speaking.

The language of space, as encoded in prepositions or other closed-class forms, seems to be a window onto a particular representational system. This system does not register everything that might be of interest about a collection of objects in space, but rather generates a stripped-down sketch of figure/ground spatial relationships. It exists alongside other representational systems that allow for a richer representation of other aspects of a scene, as needed.

The cross-cultural commonalities in the language of space suggest panhuman psychology. Further evidence for this comes from cognitive psychology, especially developmental psychology. Contrary to William James claim that an infant's world is 'a blooming buzzing confusion', babies seem to come into the world primed to recognise and track objects. Much of the evidence for this comes from studies of habituation: babies (and other folk as well) will spend more time staring at unusual events, as when an object moving behind a barrier is absent when the barrier is removed. Susan Carey (2009: 67-116) summarises the extensive evidence for 'core cognition' of objects in space, for 'representation of objects ... 
created by modular, encapsulated, perceptual input analyzers that have a long evolutionary history [and] continue to articulate our representation of the world throughout life' (ibid.: 115).

An anthropologist familiar with kin terminology who learns about the conceptual structure of objects in space may experience a sense of recognition. The connection between the language of space and its inferred conceptual structure looks a lot like the connection between the language of kinship and its inferred conceptual structure. Consider some of the parallels. Kin terms form a closed semantic domain. Although kin terms are nouns in the syntax of most languages, semantically they are more preposition-like than noun-like. They are about 'where' (metaphorically speaking), not 'what'. They denote relationships, not individual qualities - one is only aunt in relation to somebody. Kin relationships situate a figure (conventionally alter) in relation to a ground (conventionally ego). Alter is normally foregrounded, so that, for example, sex-of-alter distinctions are more common than sex-of-ego distinctions (but see the discussion of Lapp and Aboriginal Australian kinship below for motivated exceptions). Some kin types are cognitively prototypical, especially father and mother, as shown by patterns of linguistic markedness (Greenberg 1966, 1990; Shapiro Chapter 1). Kin terms differ from one another in distinctive features, and across cultures the number of such features is limited - probably not many more than the eight proposed by Alfred Kroeber (1909). These features rarely include quantities like 'more than 10 years older' (but see Gould 2000: 138-42 for an exception in Samoan), or important information like 'richer'. Even some particulars of spatial representation carry over. Distance is one dimension of variation in kin terms, and there is a vertical dimension as well, including older/ younger than ego, and ascending/descending generation. Of course, there are important differences too between kinship space and physical space; most notably kinship space is built up by compounding genealogical primitives, instead of being a preexisting background.

The parallels between physical space and kinship space are only one instance of a broader pattern in conceptual structure. Linguists have noted for some time that just about every domain of conceptual structure studied so far-including time, causation, change of state, and possession-seems to borrow some of its organisation from the conceptual structure of objects in space (Jackendoff 2002; Pinker 2007). In some ways, this puts theories of conceptual structure at odds with standard evolutionary psychology, which emphasises how different cognitive domains are specialised for the 
adaptive demands of different cognitive tasks, rather than how they share a common organisation (Barkow, Cosmides and Tooby 1992). However, these cross-domain similarities have a potential evolutionary explanation, in the principle of homology. Homology is familiar in the study of anatomy; human hands and feet differ from each other because they are specialised for walking and grasping, but they have important structural similarities because of a shared evolutionary history. By the same token, in the course of human evolution, the neurological machinery specialised for spatial cognition may have been duplicated and reassigned the task of representing more abstract domains. Very recently, neuroanatomical evidence has been collected that supports this theory (Parkinson, Liu and Wheatley 2014; Parkinson and Wheatley 2013).

On a purely adaptationist account, one might expect the evolved psychology of kinship to consist of a collection of mechanisms optimally engineered to assess coefficients of relatedness. But the conceptual structure of kinship on display in kin terminology looks more complicated than this, and may bear the marks of a deeper evolutionary history.

\section{Aboriginal Australians in kinship space}

The previous section argued that kin terminology provides an especially clear view of the conceptual structure of kinship. This section argues that the conceptual structure of kinship is involved not just in kin terminology but in kin categorisation and social organisation more generally. It traces a path from conceptual structure to social structure, from figure/ground distinctions in kin terminology to Aboriginal Australian marriage rules and sections.

As noted above, figure/ground relationships-with the figure being the focus of attention-are a major feature in the conceptual structure of both kinship and physical space. In physical space, the figure is syntactically privileged as head of a noun phrase ('the lamp on the table') or the subject of a sentence ('The lamp is on the table.'). Usually the smaller and more moveable of two objects is the figure, but exceptional circumstances lead to the reverse ('The table you're looking for is under that lamp.').

Kin terms are generally nouns, so figure/ground relationships in kinship space, involving alter, ego, and linking kin, do not show up in prepositional argument structure as they do for spatial prepositions. However, they 
may be evident in other ways, as markedness relationships involving the presence or absence of sex distinctions, for example. Typically, alter is the figure and ego is the ground. This is how English works: knowing that A is granddaughter to E, tells you the sex of A but not E. In English, both grandparent and grandchild terms mark the sex of alter, not ego, indicating that more attention is focused on alter. However, in some cases other factors dominate categorisation. Konkoma Lapp provides an example. Terms for grandparents handle sex distinctions as English does: parent's father is aggja and parent's mother is akko, giving sex of alter, not ego. But grandchild terms work the opposite way, giving sex of ego, not alter. Man's child's child is aggjot and woman's child's child is akkot, so knowing that A is akkot to E tells you the sex of E but not A (Gould 2000: 289-91). What's going on in this case is that giving the sex of the senior individual in a kin relationship (a grandparent) is more important than giving the sex of the junior (a grandchild), regardless of who is alter and who is ego.

Aggjot and akkot are inverse terms. A gloss on 'A's aggjot' is 'he/she to whom $\mathrm{A}$ is aggja (grandfather)', and a gloss on ' $A$ 's akkot' is 'he/she to whom A is akko (grandmother)'. Following Gould, these grandchild types might be labelled 'grandfatherling' and 'grandmotherling,' or Grandfather ${ }^{-1}$ and Grandmother $^{-1}$ (ibid.: 28). With these terms, ego is figure, not ground, because he or she is more perceptually salient by virtue of being senior. Consistent with their inverse status, the two grandchild terms are obvious morphological derivatives of the two grandparent terms, coming close to merging with their reciprocals.

Inverse kin terms are analysed by Joseph Greenberg (1990), and shown by George Murdock (1970) to be widespread. They are an instance of a common situation in linguistics where multiple constraints may be active-in this case, roughly, 'Emphasise alter over ego' and 'Emphasise senior over junior' - but one or the other is given precedence in cases of conflict (Jones 2010). In the rest of this section I argue that how this semantic conflict is resolved can have consequences not just for what people call their kin, but for how they organise their social lives. I look at kinship systems in Aboriginal Australia, where opting for inverse kin terms and corresponding categorisations have far-reaching social structural effects.

Although there is some variation, Aboriginal Australian kinship systems tend to fit in the broad category that anthropologists label Dravidian (Godelier, Trautmann and Tjon Sie Fat (eds) 1998; Scheffler 1978; 
Trautmann 1981). In a generic Dravidian system the suppression of lineal/collateral distinctions coexists with parallel/cross distinctions and cross/affine equations. The first two principles mean that parents are terminologically equated with same-sex siblings (parallel), but distinguished from opposite-sex siblings (cross). These mergers and distinctions also extend to more distant relations. Mother's sister's child is equated with mother's child and thus with sibling, and father's brother's child is equated with father's child and thus with sibling. These equations extend to reciprocals as well, so that man's brother's child and woman's sister's child are equated with own child. Cross/affine equations mean that cross-kin are systematically equated with affines: Mother's brother's child and father's sister's child with spouse or spouse's sibling, mother's brother with spouse's father, father's sister with spouse's mother, and man's sister's child and woman's brother's child with child's spouse. Cross/affine terminological equations are accompanied by marriage rule; opposite-sex cross-cousins are not just labelled husband and wife, but are preferred or prescribed spouses.

Most Aboriginal Australian systems depart from generic Dravidian in one important respect (Scheffler 1978; Shapiro 1970, 1979; Viveiros de Castro 1998). They start with inverse kin categories for children, so that the fundamental distinction among children is not between son and daughter but between man's child and woman's child-'fatherling' and 'motherling' in Gould's nomenclature (2000: 28)—although a secondary distinction between male and female children may be included as well. This distinction is combined with a parallel/cross distinction among siblings' children. A man's brother's child (who calls him their 'father'), along with his own child, is man's child, or 'fatherling'. A woman's sister's child (who calls her their 'mother'), along with her own child, is woman's child, or 'motherling'. The parallel/cross distinction means that the children of same-sex parents are not equated with the children of oppositesex parents, leaving several options for labelling children of cross-siblings. In the most economical case, since a man has already used up 'fatherling' for his own and his brother's children, he uses 'motherling' for his sister's children, and a woman uses 'fatherling' for her brother's children. Other terminologies add additional terms for these cross-kin types.

On the surface it looks as if there are two kinds of crossness, Dravidian and Aboriginal Australian, that differ in how they classify own and siblings' children. However, I propose that, at a deeper level, what is involved is an interaction between: (1) a single parallel/cross distinction, operating 
in both standard Dravidian and Aboriginal Australian, and (2) a seniorfocused sex distinction, operating in Australian, but not Dravidian, resulting, in $\mathrm{G}^{-1}$, in an ego-focused inverse fatherling/motherling distinction. (In addition, Dravidian and sometimes Aboriginal Australian may include the more standard alter-focused son/daughter distinction.) As we have seen in the discussion of Lapp above, it is possible to have senior-focused kin terms, with sex-of-ego distinctions when ego is senior, without parallel/cross distinctions. Treating the Dravidian/Aboriginal Australian difference as the product of the interaction of constraints already observed in other contexts is more economical than inventing new varieties of crossness.

The Aboriginal Australian classification of $\mathrm{G}^{-1}$ relatives has further structural consequences, which have been spelled out by a number of authors (reviewed by Scheffler 1978). The division of $\mathrm{G}^{-1}$ relatives into 'fatherling' and 'motherling' classes (i.e. man's child/brother's child, and woman's child/sister's child) mirrors a division of $\mathrm{G}^{1}$ relatives into father and mother. To maintain the symmetry of descending and ascending generations, father's sister can be grouped with father and mother's brother with mother. The result is to partition $\mathrm{G}^{1}$ and $\mathrm{G}^{-1}$ relatives together into two superclasses: a father/fatherling class (father, father's sibling and their reciprocals), and a mother/motherling class (mother, mother's sibling and their reciprocals). And two more superclasses may be recognised as well. In $\mathrm{G}^{0}$ there is a category of siblings and parallel kin including father's fatherling and/or mother's motherling, plus a category of potential spouses and cross-kin, including father's motherling and mother's fatherling. This $\mathrm{G}^{0}$ bifurcation can be extended to the alternating generations, $\mathrm{G}^{ \pm 2}$. In $\mathrm{G}^{2}$ the parallel class can be expanded to include father's father and mother's mother, and the cross-class to include father's mother and mother's father. In $\mathrm{G}^{-2}$ the parallel class can be expanded to include fatherling's fatherling and motherling's motherling, and the cross-class to include fatherling's motherling and motherling's fatherling.

This division into four superclasses is implicit in standard Aboriginal Australian kin categorisation. As long as people follow the rule of not marrying members of the three classes that stand to them as father, mother and sibling and marrying the fourth class that stands as crosscousin, everyone will agree on where the lines between classes are drawn.

As a number of authors have recognised, this division of kin into implicit classes is probably the basis for the section systems seen in much of Aboriginal Australia (Scheffler 1978: 432-80). 'The categories and 
intercategory relations of section and subsection systems are derived from the highest-order superclasses of systems of kin classification' (ibid.: 432). Where sections exist, each section is related to two other sections as father/ fatherling, and mother/motherling, and to one other section as crosscousin/potential spouse/potential sibling-in-law. Membership in sections is normally transmitted according to the same logic of patrifiliation and matrifiliation as membership in superclasses, although section and super-class do not always coincide exactly and additional rules are needed to resolve inconsistencies when someone's parents have made a marriage that violates the rules. In the earlier literature, sections are sometimes called marriage classes, but this is often a misnomer. In many, not all (Shapiro 1979), Aboriginal Australian groups, membership in egocentric kin categories rather than section membership is used to settle marriage rights when the two are in conflict, and the chief importance of sections is religious and ritual (Scheffler 1978: 474). This and other lines of evidence led Scheffler and others to argue that egocentric genealogical categories are logically prior to sociocentric sections. They are probably historically prior as well, with section systems developing just a few times as a reification of genealogical superclasses, and then diffusing, in some cases to societies without the corresponding kin categories. ${ }^{1}$

To further demonstrate the importance of genealogically based categorisation to social structure, compare the rather different structural possibilities inherent in standard Dravidian. At first blush, the Dravidian categorisation of kin, like that in Aboriginal Australia, seems to allow a division of relatives into four superclasses. Among generation $\mathrm{G}^{ \pm 1}$ kin, Dravidian allows a division between parallel and cross-kin (in contrast to the patrifilial/matrifilial division in Australia). Parallel $\mathrm{G}^{ \pm 1}$ kin include parents and their same-sex siblings, plus reciprocals (own children and children of same-sex siblings). Cross $\mathrm{G}^{ \pm 1}$ includes parents' opposite-sex siblings, plus reciprocals (children of opposite-sex siblings). And a $\mathrm{G}^{0}$

1 This argument could be extended further. For example, Aboriginal Australian subsection systems follow from Aranda kin categorisation, as spelled out in Scheffler (1978: 453-60). And the section systems found in scattered locations outside Aboriginal Australia (Viveiros de Castro 1998) may also derive from kin superclasses. Among Panoan-speaking groups in Western Amazonia, FZ is grouped with $\mathrm{F}$ rather than with $\mathrm{MB}$... different kinds of grandkin are distinguished from each other and equated with kin or affines at Ego's own generation. This Kariera-type terminology is in perfect agreement with their system of sociocentric, alternating generation marriage classes (Hornborg 1993: 104). One such group, the Sharanahua, lack named sections, but have just eight basic kin terms dividing Ego's kin into four Aboriginal Australian-style superclasses, further distinguished by sex or cross-sex (Siskind 1973: 47-66). 
parallel/cross distinction operates as in Aboriginal Australia, distinguishing siblings and parallel cousins from cross-cousins, who are also potential spouses.

However, in contrast to the Aboriginal Australian case, this division cannot form the basis for a sociocentric four section system, because people will disagree on who belongs to what section. A man will consider a wife or potential wife, in his own generation, to belong to the cross category, while his father will belong to the parallel category. But the position of his mother will be ambiguous; parallel to him, but cross to his father. Ego and his kin will thus not be able to agree on a division of their kin into four sections. The best that can be managed by way of sectioning in a system of Dravidian categories is a two-fold division into moieties, patrilineal or matrilineal, with own moiety and opposite moiety standing as consanguines and affines.

Aboriginal Australian and Dravidian categorisations also have different consequences for marriage rules. In generation $\mathrm{G}^{0}$, both systems are consistent with a rule of cross-cousin marriage, but they treat crossgenerational marriages differently. Under Aboriginal Australian categorisation, kin in generations $\mathrm{G}^{1}$ and $\mathrm{G}^{-1}$ fall into father/fatherling and mother/motherling superclasses, and are normally ineligible for marriage. Under Dravidian categorisation, by contrast, these relatives are merely members of the affine superclass, and may be possible or even preferred spouses (Good 1996; Trautmann 1981). Cross-generational marriages, especially between a man and his sister's daughter-an unmarriageable 'motherling' under Aboriginal Australian rules—are common in many Dravidian systems in southern India and Amazonia.

By way of summary, let us run through the argument backwards. Differences between Aboriginal Australian and Dravidian social organisation, including section systems and marriage rules, seem to derive from differences in kin categorisation: Scheffler (1978) and others make a strong case that the causal arrow runs from categorisation to social structure, rather than vice-versa.

And in turn, key differences in kin categorisation seem to derive from the possibilities inherent in the conceptual structure of kinship; in particular, from different ways of assigning figure and ground roles to 'objects' in kinship 'space'. So without denying the evidence that cosmology is enlisted as an ideological prop for Aboriginal Australian sections 
(von Brandenstein 1970), or the possibility that ecological factors are involved in the genesis of Aboriginal Australian-type systems in Australia and elsewhere, what stands out here is the way these systems seem to be exploring the combinatorial potential of conceptual structure.

\section{Conclusion: Good to think}

The study of kinship is one of the great success stories in social anthropology. Yet this empirical success is in some ways a theoretical embarrassment. Kinship rules in many societies seem to be more structured, and structured differently, than one would expect just from people helpingand not copulating with-other people according to inferred coefficients of relatedness. And the organisation of kinship categories around a set of underlying universals seems to go beyond what one would expect if kinship were just a poorly demarcated cultural domain at the intersection of social life and folk theories of heredity. Here I have made the case that kinship is also a domain of evolved conceptual structure. Sharing this conceptual structure makes it easier for people to converge on sharedkin categories and associated rules, while the permutations permitted by the structure can generate variation in kinship systems and kin-based social organisation, such as the difference between standard Dravidian and Aboriginal Australian systems. I suggest that kinship systems are as orderly as they are, and the study of kinship is as successful as it is, because human kinship is partly about what is 'good to think'.

\section{References}

Astuti, Rita. 2001. 'Are we all natural dualists? A cognitive developmental approach'. Journal of the Royal Anthropological Institute 7(3): 429-47. doi.org/10.1111/1467-9655.00071

Barkow, Jerome, Leda Cosmides and John Tooby. 1992. The Adapted Mind: Evolutionary Psychology and the Generation of Culture. Oxford University Press.

Barrett, Justin L. 1999. 'Theological correctness: Cognitive constraint and the study of religion'. Method and Theory in the Study of Religion. 11(4): 325-39. doi.org/10.1163/157006899X00078 
Beckerman, Stephen and Paul Valentine (eds). 2002. Cultures of Multiple Fathers: The Theory and Practice of Partible Paternity in Lowland South America. Gainesville, FL: University Press of Florida.

Bellwood, Peter, James J. Fox and Darrell Tryon (eds). 2006. The Austronesians: Comparative and Historical Perspectives. Canberra: ANU E Press. Online: press-files.anu.edu.au/downloads/press/p69411/ pdf/book.pdf?referer=106 (accessed 31 May 2017).

Bloch, Maurice, Gregg Solomon and Susan Carey. 2001. 'Zafimaniry: An understanding of what is passed on from parents to children: A cross-cultural investigation'. Journal of Cognition and Culture 1(1): 43-68. doi.org/10.1163/156853701300063570

Brady, Ivan (ed.). 1976. Transactions in Kinship: Adoption and Fosterage in Oceania. Honolulu: University of Hawaii Press.

Carey, Susan. 2009. The Origin of Concepts. Oxford: Oxford University Press. doi.org/10.1093/acprof:oso/9780195367638.001.0001

Caroll, Vern (ed.). 1970. Adoption in Eastern Oceania. Honolulu: University of Hawaii Press.

Carsten, Janet. 1997. The Heat of the Hearth: The Process of Kinship in a Malay Fishing Community. Oxford: Clarendon Press.

Chapais, Bernard and Carol M. Berman (eds). 2004. Kinship and Behavior in Primates. Oxford: Oxford University Press.

Christakis, Nicholas and James H. Fowler. 2014. 'Friendship and natural selection'. Proceedings of the National Academy of Sciences 111: 10796-801. doi.org/10.1073/pnas.1400825111

Darwin, Charles. 1868. The Variation of Plants and Animals under Domestication, vols I and II. London: John Murray.

DeBruine, Lisa M. 2002. 'Facial resemblance enhances trust'. Proceedings of the Royal Society 269(1498): 1307-12. doi.org/10.1098/rspb. 2002.2034

—. 2004. 'Resemblance to self increases the appeal of child faces to both men and women'. Evolution and Human Behavior 25(3): 142-154. doi.org/10.1016/j.evolhumbehav.2004.03.003 
Denning, Keith and Suzanne Kemmer (eds). 1990. On Language: Selected Writings of Joseph Greenberg. Stanford, CA: Stanford University Press.

Godelier, Maurice, Thomas R. Trautmann and Franklin E. Tjon Sie Fat (eds). 1998. Transformations of Kinship. Washington DC: Smithsonian Institution Press.

Good, Anthony. 1996. On the Non-Existence of 'Dravidian Kinship'. Edinburgh Papers in South Asian Studies, No. 6.

Goodenough, Ward H. 1965. 'Yankee kinship terminology: A problem in componential analysis'. American Anthropologist 67(5): 259-87. doi.org/10.1525/aa.1965.67.5.02a00820

Gould, Sydney Henry. 2000. A New System for the Formal Analysis of Kinship. Lantham, Maryland: University Press of America.

Greenberg, Joseph H. 1966. Language Universals, with Special Reference to Feature Hierarchies. The Hague: Mouton de Gruyter.

- 1990. 'Universals of kinship terminology: Their nature and the problem of their explanation'. In On Language: Selected Writings of Joseph Greenberg, edited by Keith Denning and Suzanne Kemmer, 310-27. Stanford, CA: Stanford University Press.

Hage, Per. 1997. 'Unthinkable categories and the fundamental laws of kinship'. American Ethnologist 24(3): 652-67. doi.org/10.1525/ ae.1997.24.3.652

Hauber, M.E. and Paul W. Sherman. 2001. 'Self-referent phenotype matching: theoretical considerations and empirical evidence'. Trends in Neuroscience 24: 609-16. doi.org/10.1016/S0166-2236 (00)01916-0

Hepper, Peter G. (ed.). 1991. Kin Recognition. Cambridge: Cambridge University Press.

Hiatt, L.R. 1996. Arguments about Aborigines: Australia and the Evolution of Social Anthropology. Cambridge: Cambridge University Press.

Hirschfeld, Lawrence A. and Susan Gelman (eds). 1994. Mapping the Mind: Domain Specificity in Cognition and Culture. Cambridge: Cambridge University Press. 
Hornborg, Alf. 1993. 'Panoan marriage sections: A comparative perspective'. Ethnology 32(1): 101-08. doi.org/10.2307/3773548

Jackendoff, Ray. 2002. Foundations of Language: Brain, Meaning, Grammar, Evolution. Oxford: Oxford University Press. doi.org/10.1093/acprof: oso/9780198270126.001.0001

Jones, Doug. 2010. 'Human kinship, from conceptual structure to grammar'. Behavioral and Brain Sciences 33(5): 367-416. doi.org/ 10.1017/S0140525X10000890

Jones, Doug and Bojka Milicic (eds). 2010. Kinship, Language, and Prehistory: Per Hage and the Renaissance in Kinship Studies. Salt Lake City: University of Utah Press.

Kahneman, Daniel. 2011. Thinking, Fast and Slow. New York: Farrar, Straus and Giroux.

Kant, Immanuel. 1781. Kritik der reinen Vernunft; Marcus Weigelt, editor, translator, Introduction, Max Müller, translator. The Critique of Pure Reason. London: Penguin Press. 2009 (references are to the translated edition).

Keesing, Roger M. 1975. Kin Groups and Social Structure. New York: Holt, Rinehart and Winston.

Kitcher, Patricia. 1990. Kant's Transcendental Psychology. Oxford: Oxford University Press.

Kroeber, Alfred L. 1909. 'Classificatory systems of relationship'. Journal of the Royal Anthropological Institute of Great Britain and Ireland 39: 77-84. doi.org/10.2307/2843284

Kuper, Adam. 1999. Culture: The Anthropologists' Account. Cambridge, MA: Harvard University Press.

Labby, David. 1976. The Demystification of Yap: Dialectics of Culture on a Micronesian Island. Chicago: University of Chicago Press.

Leaf, Murray J. and Dwight Read. 2012. Human Thought and Social Organization: Anthropology on a New Plane. Lanham, MD: Lexington Books. 
Levinson, Stephen C. 2003. Space in Language and Cognition: Explorations in Cognitive Diversity. Cambridge: Cambridge University Press. doi.org/10.1017/CBO9780511613609

Levinson, Stephen C. and David P. Wilkins. 2006a. 'Appendices'. In Grammars of Space: Explorations in Cognitive Diversity, edited by Steven C. Levinson and David P. Wilkins, 553-75. Cambridge: Cambridge University Press. doi.org/10.1017/CBO 9780511486753.016

—. 2006b. 'Patterns in the data: Towards a semantic typology of spatial description'. In Grammars of Space: Explorations in Cognitive Diversity, edited by Stephen C. Levinson and David P. Wilkins, 512-22. Cambridge: Cambridge University Press. doi.org/10.1017/ CBO9780511486753.015

Levinson, Stephen and David Wilkins (eds). 2006. Grammars of Space: Explorations in Cognitive Diversity. Cambridge: Cambridge University Press. doi.org/10.1017/CBO9780511486753

Lévi-Strauss, Claude. 1949. Les structures élémentaires de la parenté. Paris: Presses Universitaires Françaises; rev. and trans. James Harle Bell and John Richard von Sturmer, ed. Rodney Needham as The Elementary Structures of Kinship. Boston: Beacon Press, 1969 (references are to the translated edition).

Lieberman, Debra. 2009. 'Rethinking the Taiwanese minor marriage data: Evidence the mind uses multiple kinship cues to regulate inbreeding avoidance'. Evolution and Human Behavior 30(3): 153-60. doi.org/10.1016/j.evolhumbehav.2008.11.003

Lieberman, Debra, John Tooby and Leda Cosmides. 2007. 'The architecture of human kin detection'. Nature 445: 727-31. doi.org/10.1038/nature05510

Lounsbury, Floyd G. 1964. 'The structural analysis of kinship semantics'. In Proceedings of the Ninth International Congress of Linguistics, edited by H.G. Lunt, 1073-93. The Hague: Mouton de Gruyter.

Lunt, H.G. (ed.). 1964. Proceedings of the Ninth International Congress of Linguistics. The Hague: Mouton de Gruyter. 
Malinowski, Bronisław. 1929. The Sexual Life of Savages in North-Western Melanesia: An Ethnographic Account of Courtship, Marriage, and Family Life among the Natives of the Trobriand Islands, British New Guinea. London: Routledge and Kegan Paul; reprinted Boston: Beacon Press, 1987 (references are to the 1987 edition).

McCabe, Justine. 1983. 'FBD marriage: Further support for the Westermarck hypothesis of the incest taboo?' American Anthropologist 85(1): 50-69. doi.org/10.1525/aa.1983.85.1.02a00030

Murdock, George Peter. 1970. 'Kin term patterns and their distribution'. Ethnology 9(2): 165-207. doi.org/10.2307/3772782

Park, Justin H. and Mark Schaller. 2005. 'Does attitude similarity serve as a heuristic cue for kinship? Evidence of an implicit cognitive association'. Evolution and Human Behavior 26(2): 158-70. doi.org/ 10.1016/j.evolhumbehav.2004.08.013

Parkinson, Carolyn and Thalia Wheatley. 2013. 'Old cortex, new contexts: repurposing spatial perception for social cognition'. Frontiers in Human Neuroscience 7: 645. doi.org/10.3389/fnhum.2013.00645

Parkinson, Carolyn, Shari Liu and Thalia Wheatley. 2014. 'A common cortical metric for spatial, temporal, and social distance'. Journal of Neuroscience 34(5): 1979-87. doi.org/10.1523/JNEUROSCI.215913.2014

Parr, Lisa A. and Frans B.M. de Waal. 1999. 'Visual kin recognition in chimpanzees'. Nature 399: 647-48. doi.org/10.1038/21345

Pinker, Steven. 2007. The Stuff of Thought: Language as a Window into Human Nature. New York: Viking.

Polley, Sarah. 2012. Stories We Tell (documentary). Lionsgate.

Porter, Richard H. and John D. Moore. 1981. 'Human kin recognition by olfactory cues'. Physiology and Behavior 27(3): 493-95. doi.org /10.1016/0031-9384(81)90337-1

Pusey, Anne. 2005. 'Inbreeding avoidance in primates'. In Inbreeding, Incest, and the Incest Taboo: The State of Knowledge at the Turn of the Century, edited by Arthur P. Wolf and William H. Durham, 61-75. Stanford, CA: Stanford University Press. 
Read, Dwight W. 2010. 'The logic and structure of kinship terminologies: Implications for theory and historical reconstruction'. In Kinship, Language, and Prehistory: Per Hage and the Renaissance in Kinship Studies, edited by Doug Jones and Bojka Milicic, 152-72. Salt Lake City: University of Utah Press.

Rodseth, Lars and Richard Wrangham. 2004. 'Human kinship: A continuation of politics by other means'. In Kinship and Behavior in Primates, edited by Bernard Chapais and Carol Berman, 389-419. Oxford: Oxford University Press.

Romney, A. Kimball and Phillip J. Epling. 1958. 'A simplified model of Kariera kinship'. American Anthropologist 60(1): 59-74. doi.org/ 10.1525/aa.1958.60.1.02a00070

Sahlins, Marshall. 2013. What Kinship Is - And Is Not. Chicago: University of Chicago Press. doi.org/10.7208/chicago/9780226925134.001.0001

Scheffler, Harold W. 1978. Australian Kin Classification. Cambridge: Cambridge University Press. doi.org/10.1017/CBO9780511557590

Schneider, David M. 1984. A Critique of the Study of Kinship. Ann Arbor: The University of Michigan Press. doi.org/10.3998/mpub.7203

Shapiro, Warren. 1970. 'The ethnography of two-section systems'. Ethnology 9(4): 380-88. doi.org/10.2307/3773044

- 1977. 'Structure, variation, and change in 'Balamumu' social categorization'. Journal of Anthropological Research 33(1): 16-49. doi.org/10.1086/jar.33.1.3629484

- 1979. Social Organization in Aboriginal Australia. New York: St. Martin's Press.

- 2011. 'What is Malay kinship primarily about? Or the new kinship studies and the fabrication of an ethnographic fantasy'. In Kinship, Language, and Prehistory: Per Hage and the Renaissance in Kinship Studies, edited by Doug Jones and Bojka Milicic, 141-51. Salt Lake City: University of Utah Press.

Shepher, Joseph. 1971. 'Mate selection among second-generation kibbutz adolescents: Incest avoidance and negative imprinting'. Archives of Sexual Behavior 1(4): 293-307. doi.org/10.1007/BF01638058 
Silk, Joan B. 1980. 'Adoption and kinship in Oceania'. American Anthropologist 82(4): 799-820. doi.org/10.1525/aa.1980.82.4.02a 00050

- - 2001. 'Ties that bond: The role of kinship in primate societies'. In New Directions in the Anthropology of Kinship, edited by Linda Stone, 71-92. Lanham, MD: Rowman and Littlefield Publishers.

Siskind, Janet. 1973. To Hunt in the Morning. Oxford: Oxford University Press.

Stone, Linda (ed.). 2001. New Directions in the Anthropology of Kinship. Lanham, MD: Rowman and Littlefield Publishers.

Talmon, Yonina. 1964. 'Mate selection in collective settlements'. American Sociological Review 29(4): 491-508. doi.org/10.2307/ 2091199

Trautmann, Thomas. 1981. Dravidian Kinship. Cambridge: Cambridge University Press.

Viveiros de Castro, Eduardo. 1998. 'Dravidian and related kinship systems'. In Transformations of Kinship, edited by Maurice Godelier, Thomas R. Trautmann and Franklin E. Tjon Sie Fat, 332-85. Washington DC: Smithsonian Institution Press.

von Brandenstein, Carl Georg. 1970. 'The meaning of section and section names'. Oceania 41(1): 39-49. doi.org/10.1002/j.1834-4461.1970. tb01114.x

Weiner, Annette B. 1988. The Trobrianders of Papua New Guinea. Belmont, CA: Wadsworth Publishing Co.

Westermarck, Edward. 1891. A History of Human Marriage. London and New York: Macmillan and Co; reprint 1903, London: Macmillan and Co. (page references are to the reprint edition).

Wolf, Arthur. 1995. Sexual Attraction and Childhood Association: A Chinese Brieffor Edward Westermarck. Stanford: Stanford University Press.

Wolf, Arthur P. and William H. Durham (eds). 2005. Inbreeding, Incest, and the Incest Taboo: The State of Knowledge at the Turn of the Century. Stanford, CA: Stanford University Press. 
This text is taken from Focality and Extension in Kinship: Essays in Memory of Harold W. Scheffler, edited by Warren Shapiro, published 2018 by ANU Press, The Australian National University, Canberra, Australia.

doi.org/10.22459/FEK.04.2018.11 